Ali Maksum | Poros Maritim dan politik Luar Negeri Jokowi

\title{
Poros Maritim dan Politik Luar Negeri Jokowi
}

\begin{abstract}
Ali Maksum ${ }^{1}$
Abstract

This article discusses the President Joko Widodo's poros maritim dunia or global maritime axis and the Indonesian foreign policy. This policy optimistically to strengthen Indonesia's maritime capability and also to reviving the country as maritime super power as in the early history. Once Joko Widodo seizes the mandate after his dramatic victory in the last presidential election 2014, political polarization becomes a serious challenge to his administration. Yet, at the same time he obtained a huge international attention. Thus, this article attempt to understand Joko Widodo's maritime policy from foreign policy perspective. Basically, foreign policy is determined by two factors namely international and domestic. To be more systematic, this article divided into five sections i.e.; introduction, maritime axis and Jokowi's foreign policy, maritime axis and domestic politics, maritime axis and neighboring countries, and conclusion.
\end{abstract}

Keywords: maritime axis, foreign policy, international factors, domestic factors

${ }^{1}$ CenPRIS USM. Untuk tujuan akademik penulis dapat dihubungi di email : amaksum@gmail.com 
Ali Maksum | Poros Maritim dan politik Luar Negeri Jokowi

Nenek moyangku seorang pelaut

Gemar mengarung luas samudra Menerjang ombak tiada takut

Menempuh badai sudah biasa

Angin bertiup layar terkembang

Ombak berdebur di tepi pantai

Pemuda b'rani bangkit sekarang

Ke laut kita beramai-ramai

(Lirik Lagu Nenek Moyangku Seorang

Pelaut-Ibu Sud)

\section{Pendahuluan}

Ide poros maritim dunia atau "global maritime axis" adalah gagasan

besar Presiden Joko Widodo (Jokowi)

yang sudah dikampanyekan sejak

kampanye Pilihan Presiden (Pilpres) 2014.

Gagasan ini muncul di tengah berbagai

permasalahan bangsa seperti korupsi,

kebocoran anggaran, ketidakadilan dan

sebagainya. Ide poros maritim menjadi

harapan besar bangsa Indonesia agar

kembali ke jati diri sebagai bangsa pelaut.

Gagasan maritim yang sudah dimulai

diimplementasikan sudah tentu akan

berdampak kepada kebijakan luar negeri

Indonesia. Namun poros maritim juga

menimbulkan tantangan sekaligus peluang

yang apabila dapat diselesaikan bisa

menjadi driving force agar negara semakin maju. Tidak dipungkiri, reaksi juga datang

baik dari dalam maupun luar negeri yang

jika tidak ditangani dengan baik bisa

menjadi batu sandungan ide poros

maritim.

\section{Poros Maritim dan Kebijakan Luar}

\section{Negeri Jokowi}

Poros maritim merupakan gagasan

besar Presiden Jokowi yang ingin

mengembalikan kejayaan Indonesia

sebagai bangsa pelaut. Namun Presiden

Jokowi menggaris bawahi bahwa yang

dimaksud bangsa pelaut dengan ide besar

poros maritim bukanlah sekedar menjadi

“jongos-jongos di kapal. Tetapi bangsa

pelaut dalam arti kata cakrawala samudera.

Bangsa pelaut yang mempunyai armada

niaga, armada militer, yang kesibukannya

di laut menandingi irama gelombang

lautan itu sendiri." ${ }^{2}$ Namun inti dari pesan

Jokowi sebenarnya terletak pada

meningkatan infrastruktur maritim yang

\footnotetext{
2 Badan Informasi Geospasial, "Mewujudkan Indonesia Sebagai Poros Maritim Dunia yang Maju dan Mandiri," dalam http://www.bakosurtanal.go.id/beritasurta/show/me wujudkanindonesiasebagaiporosmaritimduniayang majudanmandiri (diakses 29 Januri 2015).
} 
Ali Maksum | Poros Maritim dan politik Luar Negeri Jokowi

selama ini terbengkalai. Akibatnya berbeda di mana negara hanya mengalami Indonesia kehilangan banyak peluang yang kerugian sekitar Rp. 65 triliun per tahun. seharusnya bisa menjadi sumber Oleh karena itu, bisa dibayangkan ratusan pendapatan negara. Lebih jauh lagi, ide triliun rupiah devisa negara lenyap setiap poros maritim tidak lain adalah untuk meningkatkan konektivitas antar pulaupulau yang sangat lemah akibat buruknya sarana dan prasarana. Ini merupakan agenda pokok poros maritim yang berambisi menguhubungkan ribuan kilometer garis pantai terutama dengan menambah fasilitas pelabuhan. ${ }^{3}$

Munculnya poros maritim tidak lain dilatarbelakangi oleh berbagai permasalahan di bidang kelautan. Misalnya menurut Data Badan Pemeriksa Keuangan (2013) memperkirakan potensi pendapatan sektor perikanan laut jika tanpa illegal fishing bisa mencapai Rp. 365 triliun per tahun. Namun disebabkan illegal fishing, negara mengalami kerugian sangat besar. Kementerian Kelautan dan Perikanan (2011), mempunyai temuan

\footnotetext{
${ }^{3}$ Vibhanshu Shekhar and Joseph Chinyong Liow," Indonesia as a Maritime Power: Jokowi's Vision, Strategies, and Obstacles Ahead," (Washington, D.C: The Brookings Institution, November 2014).
} 4 Badan Informasi Geospasial, "Mewujudkan
Indonesia Sebagai Poros Maritim Dunia yang Maju
dan Mandiri." 
Ali Maksum | Poros Maritim dan politik Luar Negeri Jokowi

Sebelum membahas lebih lanjut bebas-aktif, terlihat semakin menjauh dan

tentang gagasan poros maritime dan

kebijakan luar negeri, perlu dijelaskan

tentang tren kebijakan luar negeri

Indonesia dalam beberapa dekade.

Kebijakan luar negeri Indonesia tidak bisa

dilepaskan dari fondasi awal yang digagas

oleh Mohammad Hatta dengan konsep

"bebas-aktif." Landasan politik luar negeri

bebas-aktif pada dasarnya lebih

dilatarbelakangi oleh kekhawatiran

Mohammad Hatta yang tidak mau

Indonesia terseret dalam kontestasi Perang

Dingin yang baru berkecamuk pada tahun

1947..$^{5}$ Apalagi, banyak kelompok "kiri” di

tengah berkobarnya revolusi fisik dan anti-

penjajahan, condong memihak blok

komunis. Hal ini diperkuat dengan

pecahnya peristiwa berdarah

pemberontakan Partai Komunis Indonesia

(PKI) di Madiun, Jawa Timur atau

"Madiun Affairs. "6 Kebijakan luar negeri

5 Leo Suryadinata, Indonesia's Foreign Policy under Suharto: Aspiring to International Leadership (Singapore: Times Academic Press, 1997).

6 Rizal Sukma, Islam and Foreign Policy in Indonesia: Internal Weakness and the Dilemma of semakin ke "kiri." Kebijakan Sukarno di

bawah Demokrasi Terpimpin yang sering membela kelompok komunis semakin menguatkan pendapat ini. Kebijakan Konfrontasi dengan Malaysia dan perebutan Irian Barat secara militer menunjukkan agresifitas kebijakan luar negeri Sukarno yang didukung penuh blok Komunis terutama Uni Soviet dan PKI di dalam negeri. ${ }^{7}$ Sebaliknya, pada era Suharto kebijakan luar negerinya berubah total bahkan semakin ke "kanan." Ide-ide dan gagasan beroreintasi pembangunan merupakan jargon utama Suharto ketika baru memimpin Indonesia. Dampaknya, kebijakan luar negerinya tidak lain adalah mengundang sebanyak mungkin investasi asing ke dalam negeri dengan mengorbankan aspek-aspek pemerataan sosial-politik di daerah. ${ }^{8}$

Dual Identity, The Asia Foundation Working Paper, no. 11, (Jakarta: The Asia Foundation, 1999).

7 Sheldon W. Simon," Indonesia's Foreign Policy by Michael Leifer Review," Pacific Affairs, Vol. 57, No. 1 (Spring, 1984): 171-172.

${ }^{8}$ Simon, 172. 
Ali Maksum | Poros Maritim dan politik Luar Negeri Jokowi

Sementara BJ Habibie yang 20, "the third largest democracy," dan

memerintah di era transisi tidak dapat

berbuat banyak dan lebih fokus dengan

permasalahan dalam negeri. Pada era Gus

Dur kebijakan luar negeri Indonesia lebih

moderat dan lebih fokus untuk

meningkatan citra Indonesia di mata

internasional. Sebaliknya, pembangunan

ekonomi dan stabilitas kawasan menjadi

tema utama kebijakan luar negeri

Indonesia era Megawati. Dampaknya

ASEAN kembali menjadi bagian penting

dalam kerangka kebijakan luar negeri

Indonesia yang kurang mendapat perhatian

pada era Gus Dur. ${ }^{9}$ Adapun di bawah

Presiden Susilo Bambang Yudhoyono

(SBY) kebijakan luar negeri Indonesia di

atas jalur yang semakin stabil. Konsep

"many friends-zero enemy" menjadi

jargon utama. Di era SBY postur politik

internasional Indonesia semakin

meningkat seiring dengan beberapa

keberhasilan misalnya menjadi anggota G-

9 Dewi Fortuna Anwar and Harold Crouch, Indonesia: Foreign Policy and Domestic Politics, Trends in Southeast Asia Series, no. 9 (Singapore: Institute of Southeast Asian Studies, 2003). pertumbuhan ekonomi yang sangat pesat.

Selain itu, dua kemitraan strategis berhasil

ditandatangai yaitu dengan Amerika

Serikat dan China. ${ }^{10}$

Melihat tren di atas tentunya, bisa dilihat bentuk dan arah kebijakan luar negeri Presiden Jokowi. Pembentukan poros maritim tampaknya ingin menegaskan kebijakan luar negerinya yang beroreintasi pembangunan kelautan di mana sebelumnya kurang menjadi perhatian. Namun secara jelas dinyatakan oleh Presiden Jokowi sendiri bahwa bebasaktif masih menjadi basis kebijakan luar negeri Indonesia ke depan. Selengkapnya berikut kutipan pernyataan Presiden Jokowi dalam pidato perdana pasca pelantikan presiden 20 Oktober 2014.

"Saya ingin menegaskan bahwa (dalam) pemerintahan saya, Indonesia sebagai negara terbesar

10 Ratna Shofi Inayati, "Pemerintahan Susilo Bambang Yudhoyono dan Politik Luar Negeri Indonesia," Jurnal Penelitian Politik 2, no.1 (2005): 35-49. 
Ali Maksum | Poros Maritim dan politik Luar Negeri Jokowi

ketiga, dengan penduduk muslim

terbesar di dunia, sebagai negara

terbesar di Asia Tenggara akan

terus menjalankan politik luar

negeri yang bebas aktif, yang

diartikan untuk kepentingan

nasional dan untuk menciptakan

ketertiban dunia berdasarkan

kemerdekaan, perdamaian abadi

dan keadilan sosial." 11

Pernyataan Presiden Jokowi jelas

menunjukkan bahwa asas bebas-aktif

masih menjadi fondasi kebijakan luar

negeri Indonesia, meskipun diyakini akan

disesuaikan dengan situasi kontemporer.

Terkait dengan ini, Jennifer Sterling-

Folker mengatakan bahwa "sejak

berakhirnya Perang Dingin kajian

internasional menunjukkan munculnya

bidang-bidang baru seperti norma, ide-ide,

11 "Politik Luar Negeri Bebas Aktif Masih Jadi Pijakan Pemerintahan Presiden Jokowi," VOA Indonesia, 21 Oktober 2014, dalam http://www.voaindonesia.com/content/politik-luarnegeri-bebas-aktif-masih-jadi-pijakanpemerintahan-pressiden-jokowi/2490867.html (diakses 30 Januari 2015). pendidikan dan identitas." 12 Hal ini tidak berarti tema-tema tentang hard power tidak relevan dan lebih mengarah ke kajian ideational. Kajian kebijakan luar negeri, urgensi peran negara dan studi kemiliteran masih sangat relevan namun dengan sedikit modifikasi. Menurut Kenneth Waltz "demokrasi semakin menjadi tekanan, rasa saling tergantung semakin kuat dan peran institusi sebagai pelopor perdamaian dunia semakin penting."13 Waltz percaya bahawa "perubahan struktur politik internasional akan berdampak terhadap sikap dan interaksi sebuah negara. Namun tidak akan berubah kepentingan politik internasionalnya." 14 Artinya yang terjadi sebenarnya adalah perubahan dan bukan transformasi karena keadaan tersebut tidak merubah sikap ogois (self-help) sebuah negara, kecuali

12 Jennifer Sterling-Folker,"Competing Paradigms or Birds of a Feather? Constructivism and Neoliberal Institutionalism Compared," International Studies Quarterly 44, no.1 (March 2000): 97-119, 97.

${ }^{13}$ Kenneth N. Waltz, "Structural Realism after the Cold War," International Security 25, no. 1 (Summer 2000): 5-41, 6.

14 Waltz, 39. Penjelasan lain lihat Charles L. Glaser,"Structural Realism in a more complex world," Review of International Studies, 29 (2003): 403-414. 
Ali Maksum | Poros Maritim dan politik Luar Negeri Jokowi

jika sistem internasional tidak dihuni oleh

negara sama sekali. ${ }^{15}$

Secara umum, analisis kebijakan

luar negeri mempunyai empat dasar yang

menjadi ciri khas. Pertama, merupakan

teori yang multifactorial atau bisa

menerima banyak faktor. Kedua, bisa

menerima dan menggunakan lebih dari

satu variabel atau multilevel analysis.

Ketiga, analisisnya dipandang lebih

fleksibel. Hal ini karena dalam

menjelaskan atau menganalisis sebuah

kebijakan luar negeri bisa dilihat dari

berbagai sudut pandang seperti psikologi,

sosiologi, antropologi, ekonomi dan lain

sebagainya. Keempat, analisis kebijakan

luar negeri harus integratif merangkumi

berbagai disiplin ilmu pengetahuan.

Dengan masuknya berbagai unsur tersebut

maka analisis yang dihasilkan akan

semakin komprehensif. ${ }^{16}$ Dalam konteks

ini jelas kebijakan luar negeri Indonesia

15 Kata yang tercetak miring menunjukkan penekanan penulis. Lihat Waltz, "Structural Realism after the Cold War."

16 Pembahasan lanjut lihat Valerie M. Hudson," Foreign Policy Analysis: Actor-Specific Theory and the Ground of International Relations," Foreign Policy Analysis, 1(2005): 1-30. harus mempertimbangkan banyak faktor

terutama faktor internasional dan kondisi

politik dalam negeri. Khusus di level Asia

Tenggara, posisi ASEAN harus

dipertimbangkan di mana selain Indonesia sebagai salah satu negara pendiri dan terpenting dalam organisasi ini. Dewi Fortuna Anwar juga berpandangan, meskipun terjadi perubahan politik domestik, ASEAN tetap menjadi salah satu fokus Indonesia yang menganut prinsip bebas dan aktif. $^{17}$ Hal ini menunjukkan bahwa ASEAN memiliki posisi strategis bagi Indonesia dan ditopang oleh dukungan penuh negaranegara anggota akan peran sentral Indonesia dalam organisasi. $^{18}$ Pendapat yang sama juga dikemukakan oleh Ganesan dan Ramses Amer bahwa

17 Dewi Fortuna Anwar, "Key Aspects of Indonesia's Foreign Policy," dalam Indonesia: Foreign Policy and Domestic Politics," eds. Dewi Fortuna Anwar and Harold Crouch (Singapore: Institute of Southeast Asian Studies, 2003).

${ }^{18}$ Rizal Sukma," The Future of ASEAN: Towards A Security Community," paper presented at A Seminar on " ASEAN Cooperation: Challenges and Prospects in the Current International Situation," New York, 3 June 2003. 
Ali Maksum | Poros Maritim dan politik Luar Negeri Jokowi

“ASEAN memainkan peran krusial dalam

politik luar negeri Indonesia."19

$$
\text { Pada dasarnya perumusan }
$$

kebijakan luar negeri dipengaruhi oleh

keadaan internasional dan politik dalam

negeri. Lili Yulyadi Arnakim misalnya

mengatakan bahwa dinamika politik

internasional sering memaksa sebuah

negara merubah norma dan corak politik

tertentu dalam rangka mempertahankan

eksistensi dan kedahulatan negara dalam

sistem internasional. ${ }^{20}$ Perumusan

kebijakan luar negeri sendiri pada

dasarnya menurut Mohd Noor Yazid juga

dipengaruhi oleh perubahan-perubahan di

tingkat domestik dan internasional. ${ }^{21}$

Perubahan-perubahan tersebut secara tidak

langsung juga akan mempengaruhi

19 N. Ganesan and Ramses Amer, eds., International Relations in Southeast Asia: Between Bilateralism and Multilateralism (Singapore: Institute of Southeast Asian Studies, 2010), 323.

20 Lili Yulyadi Arnakim,'Hubungan Dinamik Antara Indonesia dan Malaysia Pasca Merdeka: Peranan Faktor "Co-Religio" Dalam Hubungan Dua Hala, dalam Setengah Abad Hubungan Malaysia-Indonesia, eds. Mohamad Redzuan Othman, Md Sidin Ahmad Ishak, Jas Laile S. Jaafar, Adrianus Meliala and Sri Murni (Shah Alam: Arah Publications, 2009), 359-371.

${ }^{21}$ Mohd Noor Yazid,'Indonesia-Malaysia Political Relations: the Idiosyncratic Factor in Foreign Policy Decision Making," Asian Profile 34, no.5 (October 2006): 455-476. skenario politik dalam negeri terutamanya

persepsi pemimpin (presiden/pemimpin negara) sebagai elemen penting dalam perumusan kebijakan luar negeri. Namun, persepsi seorang pemimpin juga tidak bisa dilepaskan dari pengaruh struktur politik internasional. $^{22}$ Sementara, Rizal Sukma lebih sepakat dengan Yazid yang menyatakan bahwa agenda politik global sering menekan/memaksa banyak negara untuk merubah kebijakan luar negeri dan postur pertahanannya. ${ }^{23}$ Terkait dengan adanya tekanan internasional, Dewi Fortuna Anwar mencontohkan apa yang terjadi di Indonesia pada akhir tahun 1990an. Menurut Dewi Fortuna keberhasilan proses demokrasi di Indonesia bukanlah disebabkan oleh kemelut politik domestik semata-mata, namun lebih disebabkan oleh desakan negara-negara Barat. $^{24}$ Oleh karena itu, Ratna Shofia Inayati

\footnotetext{
${ }^{22}$ Ibid., 457.

23 Rizal Sukma,"War on terror: Islam and the imperative of democracy," Asia Europe Journal, 2 (2004): 85-93, 87.

${ }^{24}$ Dewi Fortuna Anwar,"Foreign Policy, Islam and Democracy in Indonesia," Journal of Indonesian Social Sciences and Humanities, 3 (2010): 37-54, 44.
} 
Ali Maksum | Poros Maritim dan politik Luar Negeri Jokowi

menyatakan bahwa sebuah negara harus selalu mengamati skenario/trend politik internasional yang sedang berkembang. Karena, kemungkinan besar bisa memaksa sebuah negara melakukan sebuah tindakan mengikuti kehendak internasional sebagai akibat era globalisasi. ${ }^{25}$ Selain itu, dalam merumuskan kebijakan luar negeri pemerintah harus mewaspadai adanya campur tangan asing dengan berbagai kepentingannya. $^{26}$ Hal ini jelas menunjukkan bahwa faktor internasional/sistemik sangat menentukan sikap dan kebijakan luar negeri sebuah negara selain dipengaruhi konstelasi politik dalam negeri.

Agar lebih sistematis, perlu sebuah kerangka analisa (frameworks design) dalam proses perumusan kebijakan luar negeri Indonesia. Berdasarkan perbincangan di atas sebuah kebijakan luar negeri yang merupakan variabel

25 Ratna Shofi Inayati, "Pemerintahan Susilo Bambang Yudhoyono dan Politik Luar Negeri Indonesia," Jurnal Penelitian Politik 2, no.1 (2005): 35-49.

${ }^{26}$ Ratna Shofi Inayati, 47. tergantung/dependent ditentukan oleh variabel internasional (sebagai; faktor bebas/independent) dan variabel dalam negeri (sebagai; faktor bebas/independent). Secara umumnya, bentuk sikap/kebijakan luar negeri sebuah negara ada empat yaitu fleksibel, nasionalis, kompromi dan tidak melakukan tindakan/retorika saja. Di bawah ini adalah kerangka analisis perumusan kebijakan luar negeri Indonesia.

\section{Kerangka Analisis Perumusan}

Kebijakan Luar Negeri ${ }^{27}$

\begin{tabular}{|c|c|c|}
\hline $\begin{array}{l}\text { SISTEMIK } \\
\text { (Independent } \\
\text { Variable) }\end{array}$ & $\begin{array}{c}\text { DOMESTIK } \\
\text { (Independent } \\
\text { Variable) }\end{array}$ & $\begin{array}{l}\text { (Dependent } \\
\text { Variable) } \\
\text { - Fleksibel }\end{array}$ \\
\hline & & $\begin{array}{l}\text { - Nasionalis } \\
\text { - Kompromis }\end{array}$ \\
\hline
\end{tabular}

\section{Poros Maritim dan Politik Dalam}

\section{Negeri}

Secara spesifik, elemen-elemen domestik yang kemungkinan besar akan

\footnotetext{
${ }^{27}$ Diadopsi dan diubah dari Jeffrey W. Taliaferro," State Building for Future Wars: Neoclassical Realism and the Resource-Extractive State," Security Studies 15, no. 3 (July-September 2006): 464-495, 477.
} 


\section{Ali Maksum| Poros Maritim dan politik Luar Negeri Jokowi}

mempengaruhi proses perumusan gagasan tersebut. KIH terdiri dari Partai kebijakan luar negeri menurut Sterling- Demokrasi Indonesia-Perjuangan (PDI-P), Folker yaitu partai politik, opini publik, Partai Nasional Demokrat (Nasdem), media, elit politik, lembaga legislatif, Partai Kebangkitan Bangsa (PKB), Partai budaya politik, kelompok kepentingan, Hanura dan Partai Keadilan dan Persatuan bentuk pemerintahan dan status negara. ${ }^{28}$ Indonesia (PKPI). Di parlemen atau Dalam konteks isu kebijakan luar negeri Dewan Perwakilan Rakyat (DPR) Presiden Jokowi, elemen yang kelihatan mempengaruhi adalah partai politik, lembaga legislatif dan kelompok kepentingan. Dalam hal ini, perlu penjabaran lebih lanjut tentang ketiga komponen tersebut yang tampaknya memainkan peran berbeda dalam mempengaruhi serta mengkritisi kebijakan Jokowi.

Unsur partai politik sudah pasti tidak bisa dilepaskan dalam kebijakankebijakan Presiden Jokowi termasuk kebijakan luar negeri. Dalam konteks ide poros maritim sudah terlihat jelas bahwa kekuatan politik KIH berhadapan dengan Koalisi Merah Putih (KMP) yang merupakan gabungan partai pengusung Prabowo Subianto dalam Pilpres 2014 yaitu Partai Golkar, Partai Gerindra, Partai Amanat Nasional (PAN), Partai Persatuan Pembangunan (PPP), Partai Keadilan Sejahtera (PKS) dan Partai Bulan Bintang (PBB).

Untuk mengetahui konfigurasi politik di parlemen berikut tabel lengkap komposisi DPR berdasarkan hasil rekapitulasi Komisi Pemilihan Umum (KPU) 2014.

partai-partai yang tergabung dalam Koalisi Indonesia Hebat (KHI) dibelakang

${ }^{28}$ Jennifer Sterling-Folker, "Realist Environment, Liberal Process, and Domestic Politics," International Studies Quarterly 14, no.1 (March 1997): 1-25, khususnya halaman 2, 18-20. 
Ali Maksum | Poros Maritim dan politik Luar Negeri Jokowi

Peta Kekuatan KIH dan KMP di DPR ${ }^{29}$

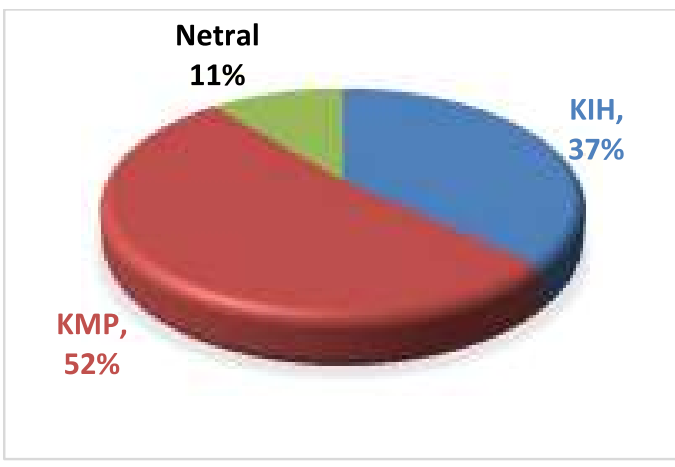

Dengan demikian, terlihat jelas

peta politik partai-partai politik di DPR.

Partai-partai tersebut alur politiknya

semakin jelas sejak polarisasi $\mathrm{KIH}$ dan

KMP pada Pilpres 2014. Sedangkan

elemen kelompok kepentingan tampaknya

lebih didominasi oleh orang-orang di

sekitar Jokowi yang tidak lain adalah tim-

sukses dan relawan. Melihat tabel di atas,

PKPI dan PBB tidak masuk dalam

rekapitulasi perolehan kursi di DPR karena

suara yang diperoleh di bawah ambang

batas parlemen (parliamentary threshold).

Namun kedua partai politik sudah

${ }^{29}$ Data diolah dari Rekapitulasi Jumlah Perolehan Suara Sah Partai Politik Secara Nasional Dalam Pemilu Anggota DPR Tahun 2014 (Jakarta: Komisi Pemilihan Umum, 2014). menyatakan komitmennya di kedua koalisi

masing-masing.

Untuk mengimplementasikan

kebijakan poros maritim dunia, Jokowi mengenalkan lima pilar utama; (1) budaya maritim, (2) menjaga dan mengelola sumber daya laut, (3) pengembangan infrastruktur dan konektivitas maritim, (4) diplomasi maritim, (5) membangun kekuatan pertahanan maritim. ${ }^{30}$ Tujuan kelima pilar tersebut tidak lain untuk meningkatkan kesejahteraan rakyat. Namun di tahapan awal beberapa kebijakan yang diluncurkan untuk mengimplementasikan pilar-pilar ini justru dikritik.

Terkait dengan kebijakan kementerian kelautan dan perikanan yang terfokus kepada penangkapan dan pembakaran kapal-kapal pencuri ikan, Himpunan Nelayan Seluruh Indonesia (HNSI) misalnya menyatakan bahwa

\footnotetext{
30 "Pidato Jokowi: Indonesia poros maritim dunia," dalam http://www.rappler.com/world/regions/asiapacific/i ndonesia/74928-pidato-jokowi-indonesia-porosmaritim-dunia (diakses 29 Januari 2015).
} 
Ali Maksum | Poros Maritim dan politik Luar Negeri Jokowi

"kebijakan sektor kelautan dan perikanan

yang otoriter dan tanpa sosialisasi untuk

dihentikan, karena tidak memberikan

peningkatan kesejahteraan kepada pelaku

usaha perikanan."

Sementara Ketua Komisi I DPR-

RI, Mahfuz Siddiq mengkritik tentang kebijakan pemerintah dalam isu penenggelaman kapal-kapal asing. Mahfuz menyarankan untuk memperkuat aspek pertahanan dahulu dan pengawasan di kawasan laut. Apa yang dikhawatirkan misalnya jika kapal Tiongkok yang ditenggelamkan, maka bisa memancing kemarahan negara terkait. Menurut Mahfuz, justeru kebijakan poros maritim Jokowi banyak memundurkan pelaku ekonomi maritim sendiri. Misalnya terkait kebijakan menaikkan harga solar sebesar Rp 2000 membuat para nelayan menjerit. Tetapi malah mereka ditargetkan

31 "Asosiasi perikanan kritik kebijakan Menteri Susi," Antara, 21 Januari 2015, dalam http://www.antaranews.com/berita/475351/asosiasi -perikanan-kritik-kebijakan-menteri-susi (diakses 23 Februari 2015). peningkatan hasil tangkapan ikan. ${ }^{32}$ Lebih lanjut, Mahfuz juga mengkritisi Jokowi yang seolah-olah seperti marketing officer dalam Forum CEO-APEC 2014 di Beijing, China. Menurut anggota Fraksi PKS ini "gagasan poros maritim bermakna membuka wilayah perairan Indonesia kepada pemain-pemain besar dunia dan apabila kondisi itu terjadi, bisa berbahaya."33

Menurut pakar kelautan Y. Paonganan, kebijakan poros maritim Jokowi harus dikaitkan dengan isu sengketa Laut Cina Selatan. Karena Laut Cina Selatan adalah jalur utama perdagangan dunia dari dan menuju AsiaPasifik yang merupakan lanjutan dari ALKI I melewati Selat Malaka. Secara langsung adalah bagian dari poros maritim dunia. Belum lagi isu Laut Cina Selatan

32 "DPR Kritik Perintah Jokowi Tenggelamkan Kapal Asing Ilegal," Republika, 25 November 2014, dalam http://www.republika.co.id/berita/nasional/politik/1 4/11/25/nfl5wm-dpr-kritik-perintah-jokowitenggelamkan-kapal-asing-ilegal (diakses 24 Februari 2015)

33 "Ketua Komisi I DPR Kritik Jokowi di APEC," dalam http://m.inilah.com/news/detail/2153484/ketuakomisi-i-dpr-kritik-jokowi-di-apec (diakses 24 Februari 2015). 
Ali Maksum| Poros Maritim dan politik Luar Negeri Jokowi

juga erat kaitannya dengan posisi Natuna

dan Kepulauan Spartly yang banyak

mengandung migas dan mineral. "Jadi

terkait konflik Laut Cina Selatan,

Indonesia tidak bisa diam begitu saja,

tetapi harus mengantisipasi kelakuan

Tiongkok yang merasa paling hebat di

Asia." Sehingga, "jika Jokowi ingin

menjadikan Indonesia sebagai poros

maritim dunia, ya harus paham masalah

Laut Cina Selatan, jika tidak ya omong

kosong namanya." 34

Kritik pedas juga datang dari

Dewan Perwakilan Daerah (DPD) RI yang

menilai kebijakan poros maritim tidak

serius seperti yang diharapkan. Salah satu

anggota DPD menganggap bahwa

kebijakan tersebut hanya untuk menarik

simpati saja pada waktu kampanye dan di

awal pemerintahannya. Misalnya

berpendapat bahwa "Jokowi dalam

debatnya menyatakan sudah terlalu lama

bangsa dan negara ini memunggungi laut.

34 "Pakar Maritim Anggap Jokowi 'Bulshit', Tak Paham Sok Bicara Poros Maritim," SuaraNews, dalam http://www.suaranews.com/2014/06/pakarmaritim-anggap-jokowi-tak-paham.html (diakses $24 / 2 / 2015)$
Kalau dia dipercaya rakyat jadi presiden, maka dia akan membangun poros maritim. Tetapi setelah memasuki bulan keempat jadi presiden, Jokowi terkesan lupa akan janji-janjinya." Salah satu indikasinya adalah pemerintah justru dalam proses pembahasan revisi APBN-Perubahan 2015 tidak memerkuat anggaran sektor maritim. Karena faktanya dana alokasi umum (DAU) maupun dana alokasi khusus (DAK) dari pusat untuk daerah kepulauan tidak berubah signifikan. "Sama sekali tidak terlihat komitmen pemerintah terhadap pembangunan negara maritim. Sejumlah daerah kepulauan seperti Provinsi Kepulauan Riau, Maluku dan Maluku Utara serta Bangka Belitung tidak berubah alokasi DAU dan DAK-nya sebagai provinsi kepulauan." ${ }^{35}$

Menghadapi berbagai kritik tersebut, berbagai pihak menanggapinya beragam. Dalam salah satu wawancara pakar manajemen Prof. Renald Kasali

\footnotetext{
35 "Mulai Curiga Jokowi Hanya Membual soal Poros Maritim," JPPN, 5 Februari 2015, dalam http://m.jpnn.com/news.php?id=285741 (diakses 24 Februari 2015).
} 
Ali Maksum | Poros Maritim dan politik Luar Negeri Jokowi

misalnya menangkis kritik pedas anggota

DPR atas pidato Jokowi dalam forum CEO-APEC dengan mengatakan bahwa

"Kalau membuat pernyataan itu hendaklah cerdas!." Karena Renald berpandangan bahwa apa yang dilakukan Jokowi sangat tepat sebagaimana Presiden Bill Clinton di masa-masa awal memegang kekuasaan yang melihat kondisi kurang baik perekonomian negaranya. Hal ini menunjukkan kesadaran tinggi Jokowi sebagai mana Bill Clinton atas keterpurukan ekonomi negaranya dengan "ikut turun tangan langsung" untuk memasarkan pesawat Boeing yang sedang mengalami kesulitan akibat kalah bersaing dengan Air Bus. Langkah yang sama juga dilakukan penerus Clinton, Barrack Obama yang juga memposisikan dirinya layaknya pegawai pemasaran. Hasilnya, pada KTT APEC, 18 November 2011, di Bali, Lion Air membeli 230 pesawat Boeing 737 dengan nilai 21,7 miliar Dollar $\mathrm{AS}^{36}$

36 "Jokowi Memang Harus Jadi "Pedagang" di
Kubu Jokowi sendiri dalam 100

hari kepemimpinannya menyatakan dukungannya terhadap gagasan poros maritim dunia. Salah satu pimpinan PDI-P Arif Budiman Menurut Arif, mengatakan "salah satunya diturunkan ke dalam konsep Restorasi Maritim Indonesia; mengatasi pasar gelap tuna dan pemanfaatan Zona Ekonomi Eksklusif (ZEE); memberantas illegal fishing, ekspansi budidaya laut; dan mengembangkan padat karya di sektor maritim.” Pendapat Arif Budiman muncul di tengah realitas bahwa tahun 2011 saja potensi pendapatan sektor perikanan laut adalah Rp 65 triliun dan terjadi illegal fishing. Sedangkan audit BPK 2012 menemukan bahwa devisa negara bisa mencapai Rp 365 triliun namun hilang karena terjadinya illegal fishing. Dengan kata lain negara kehilangan potensi devisa sebesar Rp 300 triliun. $^{37}$

KTT APEC," kompasiana.com, dalam http://ekonomi.kompasiana.com/bisnis/2014/11/13/ jokowi-memang-harus-jadi-pedagang-di-ktt-apec686396.html (diakses 24 Februari 2015).

37 "PDIP: Doktrin Maritim Jokowi Bikin Indonesia Disegani Dunia," Rakyat Merdeka, 3 Juli 2014, 
Ali Maksum | Poros Maritim dan politik Luar Negeri Jokowi

Namun seiring dengan kemelut juga dinyatakan oleh kader PDI-P lain

internal PDI-P dan KIH pasca kompromi

politik yang tidak memuaskan pasca

Pilpres 2014, beberapa pihak di PDI-P

justru melontarkan kritik. Politikus PDI

Perjuangan Adang Rukhiatna misalnya

menyatakan bahwa wacana poros maritim

Presiden Joko Widodo bertolak belakang

dengan latar belakangnya yang lahir dan

besar di Solo, Jawa Tengah dan bisa

dikategorikan sebagai orang Solo (orang

daratan). Bahkan bisa dinilai Jokowi tidak

paham dengan masalah kemaritiman,

kelautan dan tol laut secara mendalam

yang selama ini dikampanyekan. Adang

bahkan menduga "wacana kemaritiman,

kelautan dan tol laut saat ini ditunggangi

oleh banyak pihak. Kewajiban kita semua

untuk mengawal dan meluruskan obsesi

Jokowi mengenai kemaritiman, kelautan

dan tol laut itu." 38 Pendapat yang sama

dalam

http://www.rmolsumsel.com/read/2014/07/03/8988

/PDIP:-Doktrin-Maritim-Jokowi-Bikin-IndonesiaDisegani-Dunia- (diakses 24 Februari 2015).

38، Politikus PDIP Akui Jokowi Tak Paham Kemaritiman," JPPN, 17 Desember 2014 , dalam http://www.jpnn.com/read/2014/12/17/276175/Poli bahwa wacana pembentukan poros

maritim, dan kelautan yang digelontorkan

oleh Presiden Joko Widodo diduga telah ditunggangi oleh banyak pihak dan karenanya harus dikawal dan diluruskan. ${ }^{39}$

Kekhawatiran berbagai pihak

bahkan dari orang-orang di sekitar Jokowi

bukannya tanpa alasan. Sudah menjadi

rahasia umum bahwa modal dan investasi

asing telah menggurita di Indonesia.

Walaupun dari aspek kemanfaatan

ekonomi, fenomena ini bermanfaat.

Namun pada tingkat tertentu, keadaan ini

harus diperhatikan dan kalau perlu

diwaspadai. Menurut pengamat energi dari

Indonesia Resources Studies (IRESS)

Marwan Batubara, kondisi sumber daya

alam Indonesia mayoritas sudah dikelola

oleh pihak asing karena "BUMN cuma

menguasai sektor tersebut kira-kira 17

tikus-PDIP-Akui-Jokowi-Tak-Paham-Kemaritiman (diakses 24 Februari 2015).

39 "Orang PDIP Duga Poros Maritim Ditunggangi Kepentingan Banyak Pihak," dalam https:/groups.yahoo.com/neo/groups/beritasinggal ang/conversations/messages $/ 3400 \quad$ (diakses 24 Februari 2015). 
Ali Maksum | Poros Maritim dan politik Luar Negeri Jokowi

persen dan sisanya dikuasai pihak asing. ${ }^{40}$

Dampaknya jelas bisa menjalar ke

berbagai sektor termasuk sektor perikanan

dan kelautan yang menjadi ujung tombak

gagasan poros maritim dunia. Menurut

Slamet Daroyni, dari organisasi Koalisi

Rakyat untuk Keadilan Perikanan (Kiara),

justeru Undang-Undang yang ada selama

ini mengakibatkan kemiskinan masyarakat

nelayan semakin bertambah, dan celah

penguasaan asing terhadap sumber daya

ikan, semakin meningkat. Hal ini bisa

dimaknai bahwa "Konsepsi poros maritim

dan kebijakan tol laut jangan sampai

menjadi jalan bebas hambatan bagi

pemodal asing untuk terus menguasai

sektor kelautan Indonesia. ${ }^{41}$ Faktanya

sektor kelautan memang menjanjikan.

Dalam sebuah analisis misalnya

menemukan bahwa "uang yang beredar dari sektor jasa angkutan laut sepanjang tahun 2014 diperkirakan lebih dari Rp 54

triliun." Angka ini diperkirakan hanya 10

persen saja yang bersirkulasi di Indonesia, sisanya atau 90 persen lari ke luar negeri. ${ }^{42}$

Untuk lebih memperjelas

perdebatan dan sinyalemen ini bisa dilihat

dalam peta kepemilikan pihak asing atas

berbagai sumber daya alam di Indonesia.

Walaupun data berikut belum sepenuhnya

bisa diverifikasi, namun setidaknya

gambaran ini bisa menjadi bahan kajian

dan renungan menarik tentang adanya

dugaan penguasaan asing yang

mengkhawatirkan. Meskipun data berikut

menyatakan sumbernya dari BP Migas,

namun penulis mendapatkannya dari

sumber yang belum bisa dikatakan sahih

betul. Berikut disajikan data tersebut.

40 "Penguasaan Migas Oleh Asing Rugikan Negara," Koran Jakarta, 9 Mei 2014 dalam http://www.koran-jakarta.com/?11612-

penguasaan $\% 20$ migas $\% 20$ oleh $\% 20$ asing $\% 20$ rugik an\%20negara (diakses 24 Februari 2015).

41 "Poros Maritim-Tol Laut Jangan Sampai Jadi Jalan Bebas Pemodal Asing," Republika, 23 September 2014 dalam http://www.republika.co.id/berita/nasional/umum/1 4/09/23/nccwvd-poros-maritimtol-laut-jangansampai-jadi-jalan-bebas-pemodal-asing (diakses 24 Februari 2015). 42 “Asing Kuasai 90 Persen Jasa Sektor Angkutan
Laut Rabu,” JPPN, 17 Desember 2014 dalam
http://www.jpnn.com/read/2014/12/17/276171/Asi
ng-Kuasai-90-Persen-Jasa-Sektor-Angkutan-Laut
(diakses 24 Februari 2015). 


\section{Data Kepemilikan Asing di Indonesia}

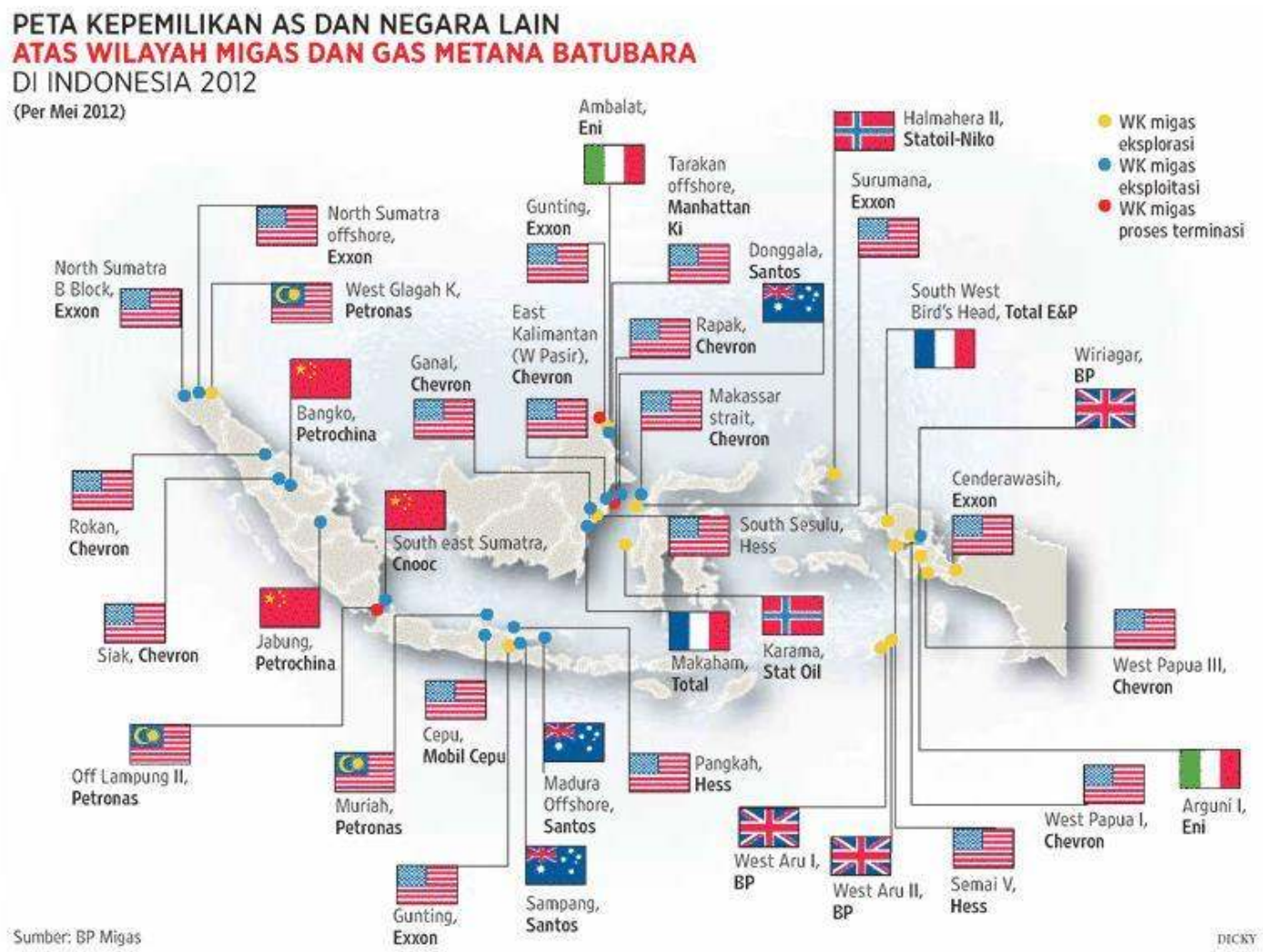

Sumber : http://www.energitoday.com/uploads//2013/01/Peta-kepemilikan-AS-dan-negaralain-atas-wilayah-migas-dan-gas-metana-batubara-di-Indonesia-20123.png investasi besar-besaran bersamaan dengan

Data di atas menggambarkan bagaimana mengguritanya penguasaan asing. Berbagai pihak di dalam negeri tentu sangat sadar tentang situasi ini. Oleh karena itu, tidak mengherankan jika presentasi Jokowi dalam pertemuan CEOAPEC di Beijing menuai banyak kritik terutamanya terkait ancaman dominasi asing. Dengan dibukanya kesempatan peluncuran poros maritim dunia terbuka juga peluang modal asing untuk menguasai sektor kelautan kita. Namun di sisi lain tidak sedikit yang mendukung bahkan mendorong gagasan tersebut segera diimplementasikan. Pada dasarnya sebagian besar pihak setuju bahwa kadahulatan sumber daya mutlak diperlukan. Terpenting menurut Pusat Studi Energi Universitas Gadjah Mada 
Ali Maksum | Poros Maritim dan politik Luar Negeri Jokowi

pembangunan yang direncanakan

"berdasar atas asas kekeluargaan dan

demokrasi ekonomi yang menjunjung

kebersamaan, efisiensi berkeadilan,

berkelanjutan, berwawasan lingkungan,

kemandirian untuk menjaga keseimbangan

\begin{tabular}{|c|c|c|c|}
\multicolumn{2}{|c|}{ KAPAL BARANG } \\
$\begin{array}{c}\text { PERINTIS SETARA } \\
\text { 208 TEUs }\end{array}$ & \multicolumn{2}{c|}{$\begin{array}{c}\text { KAPAL } \\
\text { PEAYARAN } \\
\text { RAKYAT }\end{array}$} \\
\hline $\begin{array}{c}\text { Jumlah } \\
\text { Kapal }\end{array}$ & $\begin{array}{c}\text { Miliar } \\
\text { Rupiah }\end{array}$ & $\begin{array}{c}\text { Jumlah } \\
\text { Kapal }\end{array}$ & $\begin{array}{c}\text { Miliar } \\
\text { Rupiah }\end{array}$ \\
\hline 8 & 1.280 & 50 & 2.500 \\
\hline 7 & 1.120 & 100 & 5.000 \\
\hline 4 & 640 & 120 & 6.000 \\
\hline 4 & 640 & 130 & 6.500 \\
\hline 3 & 480 & 100 & 5.000 \\
\hline 26 & 5.160 & 500 & 25.000 \\
\hline
\end{tabular}

kemajuan dan kesatuan ekonomi

Nilai Investasi pengembangan 24

nasional."43 Untuk mengetahui sejauh

mana gambaran dan potensi bangunan

poros maritim dunia Jokowi bisa dilihat

dalam skema berikut.

Skema Anggaran Pembangunan Poros

Maritim Melaui Ide Tol Laut ${ }^{44}$

\begin{tabular}{|c|c|c|c|c}
\hline \multirow{3}{*}{ TAHUN } & \multicolumn{4}{|c}{ CONTAINER } \\
\cline { 2 - 5 } & \multicolumn{2}{|c|}{$15.000 \mathrm{DWT}$} & \multicolumn{2}{c}{40.000 DWT } \\
\cline { 2 - 5 } & \multicolumn{2}{|c|}{$1.000 \mathrm{TEUs}$} & \multicolumn{2}{c}{3.000 TEUs } \\
\cline { 2 - 5 } & $\begin{array}{c}\text { Jumlah } \\
\text { Kapal }\end{array}$ & $\begin{array}{c}\text { Miliat } \\
\text { Rupiah }\end{array}$ & $\begin{array}{c}\text { Jumlah } \\
\text { Kapal }\end{array}$ & $\begin{array}{c}\text { Miliar } \\
\text { Rupiah }\end{array}$ \\
\hline 2015 & 10 & 2500 & 0 & 0 \\
\hline 2016 & 10 & 2500 & 0 & 0 \\
\hline 2017 & 9 & 2.250 & 12 & 5.400 \\
\hline 2018 & 9 & 2.500 & 12 & 5.400 \\
\hline 2019 & 8 & 2000 & 13 & 5.850 \\
\hline TOTAL & 46 & 11.500 & 37 & 16.650 \\
\hline
\end{tabular}

43 "Merebut Kembali Kedaulatan

Migas,"(Yogyakarta: Universitas Gadjah Mada) dalam http://ugm.ac.id/id/berita/8269merebut.kembali.kedaulatan.migas (diakses 24 Februari 2015).

44 "Ini Peta Tol Laut Jokowi, Program Andalan Bernilai Puluhan Triliun Rupiah," Detik, 19 November $2014 \quad$ dalam http://finance.detik.com/read/2014/11/19/073706/2 752292/4/ini-peta-tol-laut-jokowi-programandalan-bernilai-puluhan-triliun-rupiah (diakses 24 Februari 2015). 
Ali Maksum | Poros Maritim dan politik Luar Negeri Jokowi

bagian seterusnya akan didiskusikan

tanggapan negara-negara sekitar atas poros

maritim ini.

Poros Maritim dan Respon Negara-

Negara Sekitar

Ide dan kebijakan poros maritime

tampaknya sudah mendapat perhatian

banyak pengamat internasional dan

tentunya negara-negara sekitar seiring

kepopuleran Calon Presiden Jokowi. Sejak

munculnya isu pencalonan Jokowi, liputan

media asing memang signifikan. Terlepas

berbagai spekulasi yang berkembang

bahwa liputan media internasional terkait

dengan rantai kampanye, pemberitaan

tentang fenomena Jokowi tersebut menjadi

pintu gerbang dikenalnya konsep gagasan

poros maritim dunia. Dalam hal ini jelas

bahwa kebijakan poros maritim

berdampak signifikan terhadap postur

kebijakan luar negeri Indonesia. Isu

keamanan kawasan menjadi poin penting

meningkatnya diskursus tentang poros

maritim oleh berbagai negara khususnya di
Asia Pasifik terutama pasca kemenangan

Jokowi atas rivalnya Prabowo Subianto.

Amerika Serikat sebagai salah satu

mitra Indonesia misalnya cenderung

menyambut baik gagasan poros maritim

Jokowi. Melalui Asisten Menteri Luar

Negeri bidang Asia Timur dan Pasifik,

Scot Marciel menyatakan bahwa

pemerintahnya mendukung penuh langkah

Jokowi terkait poros maritim dunia. Lebih

lanjut menurut mantan Duta Besar untuk

Indonesia 2010- 2013 tersebut,

pemerintahnya mendukung dalam aspek

pembangunan infrastruktur seperti

pelabuhan yang akan mengkonektivitaskan

perairan dan kemaritiman di Indonesia. ${ }^{45}$

Bahkan terkait dengan pembangunan

besar-besaran pelabuhan, pemerintah

Rusia sudah siap untuk mensukseskan

program Jokowi. Menurut salah satu orang

terkuat nomor dua di Rusia, Indonesia

45 “AS Dukung Jokowi Jadikan Indonesia Poros Maritim Dunia," 2 Desember 2014 dalam http://m.liputan6.com/news/read/2141692/asdukung-jokowi-jadikan-indonesia-poros-maritimdunia (diakses 24 Februari 2015). 
Ali Maksum | Poros Maritim dan politik Luar Negeri Jokowi

adalah mitra terpenting di kawasan Asia

Pasifik. $^{46}$

Meskipun dukungan internasional datang dari dua negara adi daya, ise poros maritim Jokowi mulai menuai kritik dan menimbulkan kekhawatiran di kawasan. Salah satunya beranggapan bahwa gagasan Jokowi dinilai beresiko dan dilihat egois. Apalagi dengan kebijakan penenggelaman kapal, negara-negara tetangga melihatnya sebuah tanda bahaya dan menganggap kebijakan Indonesia semakin agresif dan tegas. Sambil berkata bahwa "Where some see strength as being the problem, others see weakness," kebijakan keras ini diibaratkan sebagai sebuah balance of power yang semakin mengkhawatirkan. Berikut kutipan lengkap kritik atas kebijakan Jokowi yang juga membandingkannya dengan politik luar negeri Presiden Susilo Bambang Yudhoyono (SBY):

46 "Rusia Siap Bantu Jokowi Jadikan Indonesia Poros Maritim Dunia," Harian Terbit, 12 November 2014, dalam

http://harianterbit.com/read/2014/11/12/11349/30/2

1/Rusia-Siap-Bantu-Jokowi-Jadikan-IndonesiaPoros-Maritim-Dunia (diakses 24 Februari 2015).
"If Yudhoyono's foreign policy was criticized for being too elitist and internationally oriented, then the very domestic, realpolitik flavor of Jokowi's worldview risks being perceived - rightfully or wrongfully - as over correcting this and being too insular or selfish. If countries believe Jokowi's foreign policy is geared too much toward winning votes at home rather than strengthening friendships abroad, they could also adjust accordingly and in turn complicate Indonesia's international aspirations. ",47

Hal ini menunjukkan bahwa kebijakan poros maritim yang dimulai dengan tindakan keras atas kapal-kapal pencuri ikan asing, dilihat sebagai sebuah ancaman serius. Setidaknya dari aspek persepsi ancaman dunia internasional mempunyai dua interpretasi terkait

47 “The Trouble With Indonesia's Foreign Policy Priorities Under Jokowi," The Diplomat, January 9, 2015. 
Ali Maksum | Poros Maritim dan politik Luar Negeri Jokowi

kebijakan maritim yang semakin keras

tersebut. Pertama, kebijakan ini mendesak

akan pentingnya peningkatan kekuatan

armada laut Indonesia. Artinya dalam

waktu yang tidak lama, kekuatan

Angkatan Laut bisa diprediksi bisa

menjadi ancaman serius negara tetangga.

Kedua, penguatan maritim juga bisa

diartikan bahwa Indonesia memang sedang

menghadapi ancaman keamanan serius

dari luar. ${ }^{48}$ Sehigga tidak mengherankan

jika Panglima Tentara Nasional Indonesia

(TNI) Jenderal Moeldoko berambisi untuk

menjadikan Indonesia sebagai 'big

brother' di kawasan ASEAN. ${ }^{49}$

Sementara Malaysia kelihatan

berhati-hati dan mengharapkan "semua

pihak di dalam negeri tidak

mempermasalahkan penenggelaman kapal

nelayan milik Malaysia demi menjaga

hubungan baik antar kedua negara."50

Peringatan ini muncul pasca

${ }^{48}$ Shekhar and Liow, ibid.

49 'Indonesia Keen On 'Big Brother' Role in ASEAN and Beyond: Official," The Diplomat, December 23, 2014

50 "Jangan Mempolemikkan Kejadian Kapal Nelayan Ditenggelamkan - Hishammuddin," $M$ Star, 10 Januari 2015. penenggelaman kapal nelayan Malaysia

dengan nomer pendaftaran PKFA 7738

oleh Polda Sumatera Utara. Oleh karena

itu, Panglima Tentera Laut, Laksamana

Tan Sri Abdul Aziz Jaafar mengingatkan

kepada nelayan-nelayan Malaysia untuk

"menjalankan aktivitas penangkapan ikan

di perairan Malaysia untuk menghindari

aksi penenggelaman kapal oleh pihak

keamanan Indonesia." ${ }^{\text {51 }}$ Sebaliknya,

menurut Duta Besar Indonesia untuk

Malaysia Herman Prayitno tindakan ini

sangat penting "sebagai pelajaran dan

peringatan kepada semua penangkap ikan

agar tidak mengulangi perbuatan salah

tersebut." 52

Sayangnya, akibat kebijakan poros

maritim dengan aksi-aksi penenggelaman

kapal, negara-negara sekitar juga semakin

meneliti sejauhmana tingkat dan

kemampuan pertahanan Indonesia

sesungguhnya. Secara umum, menurut

Global Fire Power armada laut Indonesia

\footnotetext{
51 "Jalankan aktiviti nelayan di perairan Malaysia sahaja," Utusan Malaysia, 5 Februari 2015.

52 "Indonesia bom kapal nelayan Malaysia," Sinar Harian, 9 Januari 2015.
} 
Ali Maksum | Poros Maritim dan politik Luar Negeri Jokowi

memiliki total kekuatan sebesar 171 kapal

termasuk Frigates (6 buah),

Corvettes (26 buah), Kapal Selam (2

buah), Kapal Pertahanan Pantai Coastal

Defense Craft (21 buah), dan Mine

Warfare (12 buah). Jumlah ini jelas sangat

tidak mencukupi untuk menjaga luas

wilayah Indonesia dengan panjang garis

pantai mencapai $54.716 \mathrm{~km}$. Singapura

yang hanya memiliki garis pantai $193 \mathrm{~km}$

saja armadanya berkekuatan 40 kapal yang

teidiri dari Frigates (6 buah), Corvettes (6

buah), Kapal Selam (6 buah), Coastal

Defense Craft (12 buah) dan Mine Warfare

(4 buah). ${ }^{53}$ Dari sisi anggaran pertahanan

juga belum memenuhi minimum essential

force yang hanya sekitar US\$8.3 miliyar

$(0,9 \%$ GDP). Alokasi ini jauh jika

dibandingkan dengan berbagai negara

yang rata-rata sudah di atas $2 \%$ dari GDP

(sudah mencapai minimum essential force)

misalnya Australia (US\$26 miliyar), China

(US\$112 miliyar), India (US\$36 miliyar),
Jepang (US\$51 miliyar) dan Korea Selatan

(US\$ 31,8 miliyar). ${ }^{54}$ Menurut Kepala Staf

TNI AL, Laksamana TNI Marsetio, poros maritim "belum dapat terwujud secara sempurna jika Indonesia belum memiliki kekuatan TNI AL yang handal dan disegani di kawasan., ${ }^{, 55}$

Dengan demikian dalam konteks ini, terlihat bahwa tanggapan negaranegara sekitar terkait poros maritim cukup beragam. Sebagian melihatnya sebagai agresifitas, namun seperti Malaysia kelihatan berhati-hati karena seringkali terlibat ketegangan masalah perbatasan yang sangat sensitif. Namun poros maritim juga menunjukkan kelemahan sesungguhnya kemampuan pertahanan Indonesia di mata negar sekitar. Tetapi, bukan tidak mungkin dalam beberapa periode mendatang, kemampuan pertahanan Indonesia bisa meningkat signifikan. Jika hal ini benar-benar terjadi, bukan tidak mungkin

\footnotetext{
${ }_{55}^{54}$ Shekhar and Liow, ibid.

55 "Visi Maritim Jokowi, Harus Didukung TNI AL yang Kuat," 11 Oktober 2014 dalam http://www.nefosnews.com/post/nasional/visimaritim-jokowi-harus-didukung-tni-al-yang-kuat (diakses 24 Februari 2015).
} 
Ali Maksum | Poros Maritim dan politik Luar Negeri Jokowi

apa yang dibayangkan oleh negara sekitar tentang agresifitas politik luar negeri Indonesia menjadi kenyataan. Paling tidak, hal ini bisa menjadi efek getar (deterrence effect) bagi negara-negara yang selama ini memandang kelemahan militer Indonesia.

\section{Kesimpulan}

Sebagai penutup, artikel ini menyimpulkan bahwa dari aspek postur kebijakan luar negeri, konsep "bebasaktif" masih dipertahankan pemerintahan Jokowi dengan beberapa penyesuaian. Terkait kebijakan poros maritim dunia, berbagai pihak dalam negeri menaggapinya secara beragam. Pro dan kontra atas kebijakan tersebut tidak lain akibat polarisasi politik pasca Pilpres 2014. Konstelasi tersebut mengakibatkan kurang padunya dukungan dalam negeri atas gagasan poros maritim namun dampaknya tidak sesignifikan dengan impementasi kebijakan tersebut. Sebaliknya, ide poros maritim dunia mendapat perhatian serius dan menjadi isu keamanan kawasan. Sebagian negara- negara sekitar melihatnya sebagai agresifitas, sebagian berhati-hati misalnya Malaysia. Kebijakan poros maritim dunia juga memunculkan evaluasi sekaligus kewaspadaan kawasan terhadap kemampuan pertahanan Indonesia sebagai negara paling penting di Asia Tenggara. Jika peluang ini benar-benar direspon dan dimanfaatkan pemerintah, otomatis bisa meningkatkan daya tawar diplomasi Indonesia tidak hanya di kawasan tetapi di tingkat global.

\section{Daftar Pustaka}

\section{Buku dan Jurnal}

Anwar, Dewi Fortuna.'Foreign Policy, Islam and Democracy in Indonesia." Journal of Indonesian Social Sciences and Humanities, 3 (2010): 37-54.

Anwar, Dewi Fortuna. "Key Aspects of Indonesia's Foreign Policy." Dalam Indonesia: Foreign Policy and Domestic Politics, " eds. Dewi Fortuna Anwar and Harold Crouch (Singapore: Institute of Southeast Asian Studies, 2003).

Anwar, Dewi Fortuna and Harold Crouch. Indonesia: Foreign Policy and Domestic Politics. Trends in Southeast Asia Series, no. 9 (Singapore: Institute of Southeast Asian Studies, 2003).

Glaser, Charles L."'Structural Realism in a more complex world." Review of 
Ali Maksum | Poros Maritim dan politik Luar Negeri Jokowi

International Studies, 29 (2003): 403 414.

Ganesan, N. and Ramses Amer. eds. International Relations in Southeast Asia: Between Bilateralism and Multilateralism (Singapore: Institute of Southeast Asian Studies, 2010).

Lili Yulyadi Arnakim.”Hubungan Dinamik Antara Indonesia dan Malaysia Pasca Merdeka: Peranan Faktor "CoReligio" Dalam Hubungan Dua Hala." Dalam Setengah Abad Hubungan Malaysia-Indonesia. eds. Mohamad Redzuan Othman, Md Sidin Ahmad Ishak, Jas Laile S. Jaafar, Adrianus Meliala and Sri Murni (Shah Alam: Arah Publications, 2009), 359-371.

Mohd Noor Yazid.'Indonesia-Malaysia Political Relations: the Idiosyncratic Factor in Foreign Policy Decision Making." Asian Profile 34, no.5 (October 2006): 455-476.

Ratna Shofi Inayati. "Pemerintahan Susilo Bambang Yudhoyono dan Politik Luar Negeri Indonesia." Jurnal Penelitian Politik 2, no.1 (2005): 35-49.

Shekhar, Vibhanshu and Joseph Chinyong Liow." Indonesia as a Maritime Power: Jokowi's Vision, Strategies, and Obstacles Ahead." (Washington, D.C: The Brookings Institution, November 2014).

Simon, Sheldon W." Indonesia's Foreign Policy by Michael Leifer Review." Pacific Affairs, Vol. 57, No. 1 (Spring, 1984): 171-172.

Sterling-Folker, Jennifer. "Competing Paradigms or Birds of a Feather? Constructivism and Neoliberal Institutionalism Compared." International Studies Quarterly 44, no.1 (March 2000): 97-119.
Sterling-Folker, Jennifer. "Realist Environment, Liberal Process, and Domestic Politics." International Studies Quarterly 14, no.1 (March 1997): 1-25.

Suryadinata, Leo. Indonesia's Foreign Policy under Suharto: Aspiring to International Leadership. (Singapore: Times Academic Press, 1997).

Sukma, Rizal."War on terror: Islam and the imperative of democracy." Asia Europe Journal, 2 (2004): 85-93.

Sukma, Rizal." The Future of ASEAN: Towards A Security Community." Paper presented at A Seminar on " ASEAN Cooperation: Challenges and Prospects in the Current International Situation," New York, 3 June 2003.

Sukma, Rizal. Islam and Foreign Policy in Indonesia: Internal Weakness and the Dilemma of Dual Identity. The Asia Foundation Working Paper, no. 11, (Jakarta: The Asia Foundation, 1999).

Taliaferro, Jeffrey W."State Building for Future Wars: Neoclassical Realism and the Resource-Extractive State." Security Studies 15, no. 3 (July-September 2006): 464-495, 477.

Valerie M. Hudson." Foreign Policy Analysis: Actor-Specific Theory and the Ground of International Relations," Foreign Policy Analysis, 1(2005): 1-30.

Waltz, Kenneth N. "Structural Realism after the Cold War." International Security 25, no. 1 (Summer 2000): 5-41.

\section{Dokumentasi Resmi}

Rekapitulasi Jumlah Perolehan Suara Sah Partai Politik Secara Nasional Dalam Pemilu Anggota DPR Tahun 2014 
Ali Maksum | Poros Maritim dan politik Luar Negeri Jokowi

(Jakarta: Komisi Pemilihan Umum, 2014).

\section{Surat Kabar}

"The Trouble With Indonesia's Foreign Policy Priorities Under Jokowi," The Diplomat, January 9, 2015.

"Indonesia Keen On 'Big Brother' Role in ASEAN and Beyond: Official," The Diplomat, December 23, 2014.

"Jangan Mempolemikkan Kejadian Kapal Nelayan Ditenggelamkan Hishammuddin," M-Star, 10 Januari 2015.

"Jalankan aktiviti nelayan di perairan Malaysia sahaja," Utusan Malaysia, 5 Februari 2015.

\section{Internet}

Badan Informasi Geospasial, "Mewujudkan Indonesia Sebagai Poros Maritim Dunia yang Maju dan Mandiri," dalam http://www.bakosurtanal.go.id/beritasurta/sh ow/mewujudkanindonesiasebagaiporosmarit imduniayangmajudanmandiri (diakses 29 Januri 2015).

"Politik Luar Negeri Bebas Aktif Masih Jadi Pijakan Pemerintahan Presiden Jokowi," VOA Indonesia, 21 Oktober 2014, dalam http://www.voaindonesia.com/content/politi k-luar-negeri-bebas-aktif-masih-jadipijakan-pemerintahan-pressidenjokowi/2490867.html (diakses 30 Januari 2015).

"Pidato Jokowi: Indonesia poros maritim dunia," dalam http://www.rappler.com/world/regions/asiap acific/indonesia/74928-pidato-jokowiindonesia-poros-maritim-dunia (diakses 29 Januari 2015).

"Asosiasi perikanan kritik kebijakan Menteri Susi," Antara, 21 Januari 2015, dalam http://www.antaranews.com/berita/475351/a sosiasi-perikanan-kritik-kebijakan-menterisusi (diakses 23 Februari 2015).
"DPR Kritik Perintah Jokowi

Tenggelamkan Kapal Asing Ilegal," Republika, 25 November 2014, dalam http://www.republika.co.id/berita/nasional/p olitik/14/11/25/nfl5wm-dpr-kritik-perintahjokowi-tenggelamkan-kapal-asing-ilegal (diakses 24 Februari 2015).

\section{"Ketua Komisi I DPR Kritik Jokowi di} APEC," dalam http://m.inilah.com/news/detail/2153484/ket ua-komisi-i-dpr-kritik-jokowi-di-apec (diakses 24 Februari 2015).

"Pakar Maritim Anggap Jokowi 'Bulshit', Tak Paham Sok Bicara Poros Maritim," SuaraNews, dalam http://www.suaranews.com/2014/06/pakarmaritim-anggap-jokowi-tak-paham.html (diakses 24/2/2015).

"Mulai Curiga Jokowi Hanya Membual soal Poros Maritim," JPPN, 5 Februari 2015, dalam http://m.jpnn.com/news.php?id=285741 (diakses 24 Februari 2015).

"Jokowi Memang Harus Jadi "Pedagang" di KTT APEC," kompasiana.com, dalam http://ekonomi.kompasiana.com/bisnis/2014/ 11/13/jokowi-memang-harus-jadi-pedagangdi-ktt-apec-686396.html (diakses 24 Februari 2015).

"PDIP: Doktrin Maritim Jokowi Bikin Indonesia Disegani Dunia," Rakyat Merdeka, 3 Juli 2014, dalam http://www.rmolsumsel.com/read/2014/07/0 3/8988/PDIP:-Doktrin-Maritim-JokowiBikin-Indonesia-Disegani-Dunia- (diakses 24 Februari 2015).

"Politikus PDIP Akui Jokowi Tak Paham Kemaritiman," JPPN, 17 Desember 2014 , dalam http://www.jpnn.com/read/2014/12/17/2761 75/Politikus-PDIP-Akui-Jokowi-TakPaham-Kemaritiman (diakses 24 Februari 2015). 
Ali Maksum | Poros Maritim dan politik Luar Negeri Jokowi

\section{"Orang PDIP Duga Poros Maritim Ditunggangi Kepentingan Banyak Pihak," dalam https://groups.yahoo.com/neo/groups/beritas inggalang/conversations/messages $/ 3400$ (diakses 24 Februari 2015).}
"Penguasaan Migas Oleh Asing Rugikan Negara," Koran Jakarta, 9 Mei 2014 dalam http://www.koran- jakarta.com/?11612- penguasaan $\% 20$ migas $\% 20$ oleh $\% 20$ asing $\% 2$ 0rugikan\%20negara (diakses 24 Februari 2015).

"Poros Maritim-Tol Laut Jangan Sampai Jadi Jalan Bebas Pemodal Asing," Republika, 23 September 2014 dalam http://www.republika.co.id/berita/nasional/u mum/14/09/23/nccwvd-poros-maritimtollaut-jangan-sampai-jadi-jalan-bebaspemodal-asing (diakses 24 Februari 2015).

"Asing Kuasai 90 Persen Jasa Sektor Angkutan Laut Rabu," JPPN, 17 Desember 2014 dalam http://www.jpnn.com/read/2014/12/17/2761 71/Asing-Kuasai-90-Persen-Jasa-SektorAngkutan-Laut (diakses 24 Februari 2015).

"Merebut Kembali Kedaulatan Migas,"(Yogyakarta: Universitas Gadjah Mada) dalam http://ugm.ac.id/id/berita/8269merebut.kembali.kedaulatan.migas (diakses 24 Februari 2015).

"Ini Peta Tol Laut Jokowi, Program Andalan Bernilai Puluhan Triliun
Rupiah," Detik, 19 November 2014 dalam http://finance.detik.com/read/2014/11/19/07 3706/2752292/4/ini-peta-tol-laut-jokowiprogram-andalan-bernilai-puluhan-triliunrupiah (diakses 24 Februari 2015).

"AS Dukung Jokowi Jadikan Indonesia Poros Maritim Dunia," 2 Desember 2014 dalam http://m.liputan6.com/news/read/2141692/as -dukung-jokowi-jadikan-indonesia-porosmaritim-dunia (diakses 24 Februari 2015). "Rusia Siap Bantu Jokowi Jadikan Indonesia Poros Maritim Dunia," Harian Terbit, 12 November 2014, dalam http://harianterbit.com/read/2014/11/12/113 49/30/21/Rusia-Siap-Bantu-Jokowi-JadikanIndonesia-Poros-Maritim-Dunia (diakses 24 Februari 2015).

"Indonesia bom kapal nelayan Malaysia," Sinar Harian, 9 Januari 2015.

Global Fire Power dalam http://www.globalfirepower.com/navy-ships.asp $(26 / 2 / 2015)$.

"Visi Maritim Jokowi, Harus Didukung TNI AL yang Kuat," 11 Oktober 2014 dalam http://www.nefosnews.com/post/nasional/vis i-maritim-jokowi-harus-didukung-tni-alyang-kuat (diakses 24 Februari 2015).

http://www.energitoday.com/uploads//2013/01 /Peta-kepemilikan-AS-dan-negara-lain-ataswilayah-migas-dan-gas-metana-batubara-diIndonesia-20123.png (diakses 24 Februari 2015). 